\title{
Determinan Proporsi Pembiayaan Murabahah BPR Syariah
}

\author{
Ninik Lukiana \\ Program Studi Manajemen, STIE Widya Gama Lumajang \\ Email : ibundaninik@gmail.com
}

\begin{abstract}
Abstrak
Seiring dengan perjalanan waktu perbankan syariah di Indonesia selain menawarkan dua produk yaitu mudharabah dan musyarakah (Profit Loss Sharing/PLS) yang merupakan pembiayaan dengan basis bagi hasil, juga menawarkan satu produk yang lebih dominan berkontribusi yaitu pembiayaan murabahah/Non PLS, termasuk di Bank Pembiayaan Rakyat Syariah (BPRS) Jawa Timur. Pembiayaan murabahah mempunyai kepastian dalam nilai cicilan, jaminan dan dapat mengurangi tingkat risiko pembiayaan. Tujuan studi untuk menganalisis determinan Pembiayaan Murabahah pada BPR Syariah di Jawa Timur, dengan batasan determinannya adalah CAR (Capital Adequacy Ratio), FDR (Financing To Deposit Ratio), dan NPF (Non Performing Financing). Jenis penelitiannya merupakan penelitian desktiptif dengan pendekatan kuantitatif data sekunder, dan populasinya semua Bank Pembiayaan Rakyat Syariah Jawa Timur yang tercatat dalam OJK (Otoritas Jasa Keuangan) periode 2015-2017, dengan teknik purposive sampling jumlah sampelnya 26 bank. Teknik analisisnya adalah analisis linier berganda, dengan hasil studi bahwa CAR dan NPF mempengaruhi pembiayaan murabahah, dan FDR tidak mempengaruhi pembiayaan murabahah. Penelitian kedepannya disarankan untuk menambah variabel dependen dan independen serta populasi penelitian.
\end{abstract}

Kata Kunci: Capital Adequacy Ratio (CAR), Capital Adequacy Ratio (FDR), Non Performing Financing (NPF), dan Pembiayaan Murabahah.

\begin{abstract}
Along with the passage of time Islamic banking in Indonesia in addition to offering two products, namely financing on the basis of profit loss sharing, namely mudharabah and musyarakah (Profit Loss Sharing (PLS), also offers a more dominant product have a contribution, namely murabaha financing/Non PLS, also occurred at the Sharia Rural Banks in East Java. This is because the characteristics of murabaha are certain in magnitude installments and margins and can reduce the level of financing risk. The purpose of this study is to determine the factors that influence Murabahah Financing in Islamic Rural Banks in East Java Province, with the limitation of these factors are the Capital Adequacy Ratio $(C A R)$, Financing to Deposit Ratio (FDR), and Non Performing Financing (NPF). This type of research is a descriptive study with a quantitative approach secondary data, and the population of all Sharia Rural Banks in East Java recorded in the Financial Services Authority (OJK) for the 2015-2017 period, with a purposive sampling technique the amoun of samples is 26 banks. The analysis technique is multiple linear analysis, with CAR and NPF research results affecting Murabahah Financing, and FDR does not affect Murabahah Financing. His subsequent research is expected to add to the dependent and independent variables as well as the study population.
\end{abstract}




\section{Keywords: Capital Adequacy Ratio (CAR), Capital Adequacy Ratio (FDR), Performing Financing (NPF), and Murabahah Financing}

Non

\section{PENDAHULUAN}

Meningkatnya pertumbuhan perbankan di Indonesia sangat signifikan dan cepat bersamaan meningkatnya kebutuhan akan jasa perbankan oleh masyarakat. Masyarakat saat ini menginkan proses cepat dan mudah sejalan dengan meningkatnya mobilitas masyarakat. Langkah untuk mempermudah masyarakat melakukan transaksi pihak bank menyediakan berbagai macam servis. Tetapi masyarakat tidak memanfaatkan jasa perbankan, karena beberapa faktor antara lain masyarakat masih meragukan implemetasi system konvensional tentang bunga bank. Masyarakat masih banyak mempermasalahkan adanya bunga yang merupakan larangan bagi kaum muslim sebagai riba. Sebagai solusinya adalah adanya perbankan yang mempunyai prinsip hukum Islam dalam kegiatan perbankan disebut dengan prinsip syariah. Peran perbankan sangatlah penting dalam memotivasi perekonomian Indonesia, karena perbankan adalah sebagai pengumpul dana dari pihak yang surplus dana untuk disalurkan pada pihak yang difisit dana, sebagai tempat masyarakat menabung yang efektif dan produktif, dan mempermudah dan mempercepat transaksi pembayaran di semua bidang perekonomian.

Prestasi perbankan di Jawa Timur selama 2018, secara global mengalami peningkatan yang konstrutif, khususnya perbankan syariah. Pertumbuhan Bank Pembiayaan Rakyat Syariah (BPRS) di Jawa Timur ini sejalan dengan peningkatan perekonomi Jawa Timur melebihi ratarata nasional. Sektor perbankan di Jawa Timur menunjukkan kecenderungan naik terbukti adanya meningkatnya total usaha perbankan senilai $6,28 \%$, yang didukung dengan peningkatan Dana Pihak Ketiga (DPK) senilai 7,82 persen, dan kredit 10,68 persen (kabarbisnis.com). Kepala Otoritas Jasa Keuangan (OJK) mengatakan bahwa perubahan peningkatan perbankan syariah sangat besar dari pada peningkatan perbankan umum lainnya di Jawa Timur, hal ini mengisyaratkan pada tahun 2018 kepercayaan masyarakat terhadap bank syariah mengalami peningkatan yang sangat berarti. Tetapi perbankan syariah di Jawa Timur tetap berusaha meningkatkan asas hati-hatian dalam mengeluarkan pembiayaan, karena adanya ketidakpastian dari kredit perbankan syariah di Jatim mengalami trend meningkat, yaitu dengan naiknya rasio NPF dari 2,74 persen pada triwulan ke tiga tahun 2017, menjadi 5,23 persen di triwulan ke tiga di tahun 2018. BPRS harus dapat lebih menyesuaikan diri dan mempunyai terobosan-terobosan dalam menyusun strategi perencanaan usaha, yaitu stategi mengumpulkan dan memberikan modal kepada publik dan strategi melaksanakan aktivitas operasional bank secara tepat dan daya guna. Pertumbuhan BPR Syariah di Jatim sangat diperhatikan oleh OJK, agar kepercayaan dan minat masyarakat kepada BPRS tetap terjaga dan selalu mengalami peningkatan. OJK setiap tahun secara rutin mengevaluasi dan memonitoring tingkat prestasi BPR Syariah (Cahyono; 2018).

Perbankan syariah awal pertumbuhan telah menghasilkan jasa perbankan bebas bunga yang disebut dengan Profit and Loss Sharing (PLS), yaitu: mudharabah dan musyarakah dengan sistem bagi hasil dengan nasabah. Tetapi dalam perkembangan usaha jasa perbankan dan perubahan keinginan nasabah, dua produk tersebut mengalami penurunan. Nasabah tidak hanya menginginkan bagi hasil dengan bank, tetapi juga menginginkan bagi risiko, maka Bank Pembiayaan Rakyat Syariah (BPRS) Jatim menawarkan satu produk yang lebih dominan berkontribusi yaitu pembiayaan murabahah/Non PLS. Pembiayaan murabahah 
mempunyai kepastian dalam nilai cicilan, jaminan dan dapat mengurangi tingkat keterbukaan terhadap kemungkinan rugi.

Murabahah adalah transaksi pembiayaan produk antara bank dan nasabah dengan kesepakatan pihak perbank menjalankan pembelian/pemesanan produk yang diminta nasabah, yang dijual kepada nasabah senilai harga pokok dengan profit bank, pembayaran secara tunai atau mengangsur, pembiayaan barang dapat dipakai sebagai modal usaha, investasi atau konsumtif. Rivai dan Arviyan (2010:145) menyatakan bahwa pembiayaan murabahah adalah transaksi pihak bank dengan nasabah dengan pihak bank menyampaikan nilai keuntungan. $B a^{\prime} i$ almurabahah menurut Rusyd adalah transaksi jasa oleh produsen yang menyampaikan informasi kepada konsumen tentang harga pokok jasa sebelum ditambah dengan profit yang ditetapkan sebelumnya oleh produsen (Antonio, 2011:107). Murabahah dilaksanakan dengan dua cara, antara lain transaksi dengan pesanan dulu dan tanpa pesanan. Hasil studi yang telah dilakukan banyak yang membuktikan bahwa bank syari'ah lebih dominan menawarkan pembiayaan murabahah, berarti bagi bank syariah pembiayaan murabahah lebih menguntungkan dari pembiayaan lainnya. Hai ini karena ada beberapa kelebihan dari pembiayaan murabahah, yaitu pertama adanya kepastian terjadinya pembelian dari pihak nasabah, artinya pihak bank syariah akan membelikan suaru produk karena sudah ada pesanan dari pembelinya. Kedua adanya kepastian profit, artinya bank syariah pasti akan mendapat keuntungan dari produk yang dijual. Ketiga adanya kemudahan dalam menerapkannya pada saat ini (Vogel dan Hayes, 1998). Pembiayaan murabahah mengalami peningkatan juga karena mempunyai tingkat kerugian lebih kecil dan pemilik perusahaan lebih aman.

Semakin meningkatnya pangsa pasar di bank syariah adalah jasa pembiayaan, oleh karena itu masih perlu dilakukan riset tentang determinan pembiayaan yang diberikan ke nasabah bank syariah. Dua penyebab yang berpengaruh terhadap pendapatan di sektor perbankan menurut Rose dan Kolari (1995), yaitu faktor dari luar dan faktor dari dalam perusahaan. Faktor dari luar perusahaan: peningkatan atau penurunan teknologi pengiriman produk, tingkat persaingan lembaga keuangan lainnya, hukum dan peraturan mengenai lembaga keuangan, juga regulasi pemerintah yang berpengaruh terhadap sistem ekonomi dan keuangan. Faktor faktor dari dalam perusahaan: tingkat daya guna kebuthan faktor-faktor produksi, tingkat kendali biaya, policy perpajakan, tingkat likuiditas dan risiko (Prastanto, 2013:83). Determinan pembiayaan murabahah, antara lain adalah: Capital Adequacy Ratio (CAR), Financing to Deposit Ratio (FDR), dan Non Perfoming Financing (NPF).

Capital Adequacy Ratio (CAR) adalah menunjukkan kecukupan modal suatu bank dalam mempertahankan keberlanjutan bisnisnya dalam jangka panjang, bank harus menyediakan modal sendiri secara optimal dalam mengimbangi sumber dana eksternal. Rivai, dkk (2013:853) mengatakan bahwa CAR salah satu rasio yang menunjukkan suatu bank mampu untuk membiayai kerugian karena adanya penurunan harta yang dimiliki oleh suatu bank. CAR menurut Mizan (2017:77) adalah menunjukkan kemampuan suatu bank dalam menyiapkan modal (baik bersumber dari internal maupun dari eksternal) untuk ekspansi dan tingkat risiko yang ditimbulkan dalam aktivitas operasionalnya.

Pembiayaan murabahah yang disalurkan kepada masyarakat harus ditentukan dengan melihat tingkat kecukupan modal (CAR) bank syariah, artinya dengan modal yang mengalami peningkatan maka suatu bank dapat menyalurkan pembiayaan murabahah yang lebih banyak, dan sebaliknya. Capital Adequacy Ratio (CAR) menurut Dendawijaya (2005:21) adalah menunjukkan tingkat jumlah aset bank yang mempunyai risk (pembiayaan, penyertaan, surat 
berharga, tagihan pada bank lain) ikut dibiayai dari modal internal elain mendapatkan modal eksternal bank, antara lain dana masyarakat, pinjaman, dan sebagainya. Hasil penelitian Wardiantika dan Kusumaningtias (2014), Kusnianingrum (2016), menunjukkan Capital Adequacy Ratio (CAR) mempunyai hubungan searah dengan pembiayaan murabahah, artinya semakin meningkta nilai CAR menujukkan bahwa bank telah memiliki modal yang cukup optimal dalam menunjang kebutuhannya serta menanggung tingkat risiko yang ditimbulkan termasuk risiko pembiayaan. Berbeda dari hasil studi empiris Fahrudin (2009), Lestari (2014), Dyatama dan Yuliadi (2015), dan Ali dan Miftahurrohman (2016) yang membuktikan bahwa CAR mempunyai pengaruh berlawanan arah terhadap pembiayaan murabahah, dengan semakin meningkatnya modal suatu bank maka semakin menurun penyaluran pembiayaan murabahah ke masyarakat.

Suatu bank mampu atau tidak mampu dalam mengembalikan kembali kewajiban jangka pendeknya kepada nasabah menginvestasikan modalnya dengan pembiayaan yang sudah diberikan kepada pihak peminjam dapat di ukur dan di analisis dengan rasio likuiditas bank, antara lain dengan FDR (Financing to Deposit Ratio). Rasio likuiditas bank menurut Nurbaya (2013) adalah perbandingan tingkat kemampuan bank dalam membayar hutang lancarnya dan permohonan kredit atau pembiayaan dengan cepat Rasio Financing to Deposit Ratio menurut Muhammad (2009) adalah perbandingan antara jumlah pembiayaan yang diberikan oleh bank dengan jumlah dana masyarakat yang dihimpun/diperoleh oleh bank. Usanti dan Shomad (2013:66) menyatakan bahwa dengan menetapkan FDR pihak bank Syariah harus hati-hati dalam memberikan pembiayaan tidak dengan hanya untuk mendapatkan pprofit atau untuk dalam waktu cepat meningktakan jumlah aktivanya, jika terjadi hal tersenut akan berdampak negatif terhadap kelangsungan hidup Bank Syariah, yang akhirnya berdampak negatif terhadap dana simpanan para nasabah. Semakin meningktanya FDR maka pembiayaan murabahah yang disalurkan juga semakin besar. Teori ini didukung hasil oleh penelitian Prastanto (2013), Kusnianingrum dan (2016), dan Rahman dkk. (2017) yang membuktikan FDR berpengaruh postif terhadap pembiayaan murabahah, tetapi hasil penelitian Rimadhani (2011) dan Katmas (2014), dan Adzimah (2017) menunjukkan FDR berpengaruh negatif terhadap pembiayaan murabahah.

Bank Syariah dalam mendapat keuntungan dari pembiayaan ada kemungkinan adanya pembiayaan bermasalah yang akan berdampak adanya tidak ada kesempatan bank mendapatkan profit dari pemberian pembiayaan tersebut. Jumlah kredit macet dapat dikarenakan adanya faktor dari luar pihak nasabah maupun faktor dari dalam bank. Tingkat risiko kemungkinan jumlah pembiayaan tidak dapat ditagih yang dihadapi bank, pembiayaan yang mempunyai masalah adalah salah satu ketidakpastian dalam proses realisasi pembiayaan di Bank Syariah, hal ini terjadi disebebkan nasabah tidak semuanya mempunyai ruang bisnis yang sama satu, dan dapat di ukur salah satunya dengan NPF (Non Performing Financing). Katagori pembiayaan bermasalah menurut Siamat (2005) disebut Non Performing Financing (NPF). Menurut Rivai (2006) Non Performing Financing merupakan salah satu ketidakpastian yang dihadapi oleh bank yaitu ketidakpastian tidak terbayarnya dan pembiayaan yang diberikan oleh bank yang disebut dengan tingkat risiko pembiayaan. Pembiayaan termasuk dalam NPF menurut Gumilarty (20016) yang sudah ditetapkan oleh Bank Indonesia adalah pembiayaan yang tidak lancar, diragukan dan tidak tertagih. Sehingga bank harus berusaha untuk menurunkan tingkat NPF, artinya jika semakin menurun tingkat NPF maka pembiayaan yang disalurkan oleh bank syariah akan meningkat, sebaliknya semakin meningkat NPF, maka pembiayaan yang diberikan oleh bank syariah akan menurun. Bank harus berusaha untuk menurunkan tingkat NPF, artinya jika semakin rendah tingkat 
NPF maka pembiayaan yang disalurkan oleh bank syariah akan meningkat. Hasil riset tentang NPF dengan pembiayaan murabahah menunjukkan adanya hubungan yang sangat signifikan, pernyataan ini didukung hasil riset yang dilakukan oleh Sari (2011), Gumilarty (2016), Angraini (2016) dan Sulistya (2017). Bertentangan dari hasil riset Prasasti (2011), Wardiantika dan Kusumaningtias (2014), dan Umi (2016), yang mengatakan bahwa Non Performing Financing tidak berdampak yang signifikan terhadap pembiayaan murabahah.

Adanya beberapa hasil penelitian yang tidak mendukung teori dan adanya kesenjangan hasil riset dari penelitian sebelumnya juga untuk memperkuat teori dan hasil penelitian sebelumnya pada sektor perbankan syariah di Indonesia, maka masih layak dilakukan riset lanjutan dampak CAR, FDR dan NPF terhadap pembiayaan murabahah. Dan perumusan masalah penelitian ini adalah: a) apakah terdapat pengaruh CAR terhadap pembiayaan murabahah?, b) apakah terdapat pengaruh FDR terhadap pembiayaan murabahah?, c) apakah terdapat pengaruh NPF terhadap pembiayaan murabahah?

\section{METODE PENELITIAN}

Penelitian ini menggunakan penelitian kuantitatif karena data penelitian berupa angka dengan analisis data dengan analisis statistik untuk menguji hipotesis. Berdasarkan tingkat eksplanasinya termasuk penelitian asosiatif karena penilitian ini mempunyai tujuan untuk menganalisis dampak dan hubungan antara variabel yang mempengaruhi yaitu CAR (Capital adequacy Ratio), FDR (Financing to Deposit Ratio), dan Non Perfoming Financing (NPF) dengan variabel yang dipengaruhi yaitu pembiayaan murabahah. Populasi penelitian ini adalah Bank Perkreditan Rakyat Syariah (BPRS) Provinsi Jawa Timur periode 2015-2017 berjumlah 30 bank, dengan teknik purposive sampling sebanyak 26 bank terpilih, maka sampel penelitian 78 laporan keuangan (26 bank x 3 tahun). Jenis data sekunder berupa runtut waktu/time series data publis laporan keuangan, dan teknik pengumpulan data dengan library research dengan mengumpulkan data dengan membaca, mempelajari, dan menganalisis literatur dari buku, jurnal yang ada kaitannya dengan penelitian ini untuk memperoleh data yang valid. Metode analisis data penelitian ini model analisis linier berganda yang harus memenuhi asumsi normalitas dan bebas dari asumsi klasik (uji multikolinieritas, autokorelasi, dan heterokedastisitas), dengan model persamaan regresi linier berganda penelitian: $P M=\alpha+\beta_{1} C A+\beta_{2} F D R+\beta_{3} N P F$. Untuk mengetahui adanya pengaruh variabel independen CAR, FDR, dan NPF terhadap proporsi pembiayaan murabahah dilakukan uji t.

\section{HASIL DAN PEMBAHASAN}

Hasil uji asumsi normalitas dari grafik P-P Plot adanya gambar grafik yang normal dari gambar titik-titik terletak di sekitar garis melintang, artinya model regresi riset ini berdistribusi normal, artinya model regresi liner berganda berdistribusi normal. Hasil uji asumsi klasik, hasilnya variabel bebas penelitian ini bebas dari gejala multikolinieritas/ variabel indepen peneiltian ini saling independen, dari hasil uji menunjukkan nilai variabel independen VIFnya kecil, ke tiga variabel independen $<10$ dan nilai tollerance $>0,1$. Dan model regresinya bebas autokorelasi dari hasil Durbin-Watsion (DW) nilainya 2,458, nilai $\mathrm{dU}=1,7129$ dan $\mathrm{dL}=1,5535$ maka $\mathrm{dU}<\mathrm{DW}<4$-dL, yaitu 1,652 $<2,458<2,857$ artinya bebas dari autokorelasi. Hasil uji output scatterplot adanya tersebarnya titik-titik dan tidak membentuk pola tertentu dengan jelas, artinya tidak terjadi adanya heteroskedastisitas yaitu muncul ketidaksamaan varians dari residual satu ke pengamatan ke pengamatan yang lain. 
Dan hasil analisis regresi berganda didapatkan persamaan: $\mathrm{PM}=75,558+0,319 \mathrm{CA}$ 0,004FDR - 0,319NPF. Hasil riset membuktikan bahwa CAR mempunyai hubungan searah dengan pembayaran murabahah, tetapi FDR, dan NPF berhubungan negatif dengan pembiayaan murabahah.

Tabel 1. Hasil Regresi dan Uji t

\begin{tabular}{llllll}
\hline No & Variabel Independen & Koefisien Regresi & t & sig & Hasil \\
\hline 1 & Constan & 75,558 & & & \\
2 & CAR & 0,319 & $-10,659$ & 0,000 & Berpengaruh Positif \\
3 & FDR & $-0,004$ & $-1,673$ & 0,921 & Tidak Berpengaruh \\
4 & NPF & $-0,319$ & $-2,364$ & 0,006 & Berpengaruh Negatif \\
\hline
\end{tabular}

Sumber: Data sekunder diolah (2019)

Pengujian t membuktikan bahwa CAR dan NPF berpengaruh pada pembayaran murabahah, hal ini disebabkan karena nilai signifikansinya $\mathrm{CAR}=0,000<0,05$ dan NPF $=0,006<0,05$. Sedangkan tidak terdapat pengaruh FDR terhadap pembayaran murabahah karena nilai signifikansi FDR $=0,921>0,05$.

Tabel 2. Hasil Uji F

\begin{tabular}{cccc}
\hline Keterangan & F & Sig & Hasil \\
\hline Regression & 7,692 & 0,000 & Berpengaruh \\
\hline
\end{tabular}

Sumber: Data sekunder diolah (2019)

Pengujian $\mathrm{F}$ hasil probabilitas $=0,000$ dannilai $\mathrm{F}_{\text {hitung }}=7,692$. Nilai probabilitas $<0,05$, artinya hasil menunjukkan NPF, FDR, CAR dipakai dalam model riset ini secara bersamasama dapat menjelaskan variabel dependen pembiayaan murabahah, dan hasil koefisien determinasi (Adjusted $R$ Square) = 0,207 (20,7\%), berarti 20,7\%, berarti variasi ke tiga variabel independen (CAR, FGR, dan NPF) mampu menjelaskan sebagian (20,7\%) variasi yang terdapat dalam variabel pembiayaan murabahah dan sisanya senilai $79,3 \%$ variasi lainnya dijelaskan oleh variabel lain yang tidak dimasukkan dalam model ini.

Hasil riset menemukan perbandingan rasio kecukupan (CAR) mempunyai hubungan searah, berpengaruh signifikan terhadap pembayaran murabahah, artinya jika Capital Adequacy Ratio (CAR) naik maka pembiayaan murabahah juga naik, dan jika CAR mengamali penenurunan maka pembayaran murabahah juga mengalami penurunan. Semakin meningkat CAR menunjukkan pihak bank telah mempunyai dana yang kecukupan untuk memenuhi keperluaannya dengan menjamin risiko yang timbul tertanam didalamya risiko pembiayaan, dan jika CAR kecil maka berdampak pada bank akan kesulitan sehingga berdampak juga tingkat kesehatan bank menurun. Hasil riset menunjukkan pihak manajemen perbankan syariah di Jawa Timur benar-benar berhati-hati dalam memenej tingkat risiko dari asset yang dimiliki, sehingga pihak bank dapat memenuhi tingkat kecukupan modal (CAR), maka penyaluran pembiayaan murabahah akan meningkat, dampaknya juga akan meningkatnya profit dan kesehatan bank syariah. Hasil riset ini sesuai dengan teori dan sependapat dengan hasil risetnya Wardiantika dan Kusumaningtias (2014), Kusnianingrum (2016), dan bertententangan dengan hasil penelitian Kamtas (2014) dan Lestari (2014), Dyatama dan Yuliadi, Ali dan Miftahurrohman (2016), Adzimah (2017:53) bahwa CAR mempunyai dampak berlawanan arah terhadap pembiayaan murabahah, artinya jika tingkat kecukupan 
modal (CAR) mengalami penurunan, maka penyaluran pembiayaan murabahah akan menurun, dan dampaknya juga akan rendahnya tingkat profit dan kesehatan bank syariah.

Hasil riset ini juga menemukan bahwa Financing to Deposit Ratio (FDR) berhubungan yang berlawanan arah dengan pembayaran murabahah tetapi tidak berpengaruh, atinya jika tingkat FDR turun maka pembiayaan murabahah naik dan sebaliknya. Tetapi peningkatan dan penurunan FDR tidak mempunyai dampak pada penurunan dan naiknya tingkat penyediaan uang yang diberikan pihak bank. Hasil membuktikan tingkat likuiditas bank syariah tidak berpengaruh terhadap pembiayaan murabahah, semakin meningkat atau menurun tingkat likuiditas bank syariah, maka akan tetapi tidak signiifikan terhadap perubahan (naik atau turun) pembiayaan murabahah. Semakin naik atau turun modal dari pihak ke tiga (DPK) yang disalurkan pihak bank syariah jenis pembiayaan, tidak mempengaruhi meningkat atau menurunnya pembiayaan murabahah. Hasil penelitian tidak berpengaruh hal ini nampak dalam data beberapa bank syariah yaitu: PT BPRS Amanah Sejahtera selama tiga periode FDR mengalami peningkatan, tetapi tingkat pembiayaan murabahah tahun 2016 mengalami kenaikan tetapi tahun 2017 turun. PT BPRS Lantabur Tebuireng FDR tahun 2016 mengalami penurunan dan tahun 2017 meningkat, tetapi tingkat pembiayaan murabahah selama tiga periode berturut-turut mengalami kenaikan. Hasil riset tidak mendukung teori dan sama dengan hasil penelitian Rimadhani (2011), Nurbaya (2013), dan Edriana (2015), tetapi hasil penelitian Katmas (2014), dan Adzimah (2017) menunjukkan FDR berdampak berlawanan arah terhadap pembiayaan murabahah. Dan bertentangan dengan hasil riset Prastanto (2013), Kusnianingrum (2016), dan Rahman dkk. (2017) menunjukkan FDR berpengaruh positif pada pembiayaan murabahah.

Hasil riset juga membuktikan bahwa Rasio tidak melakukan pembiayaa (NPF) berdampak pada proporsi pembayaran murabahah dengan arah berlawanan artinya jumlah proporsi pembayaran murabahah semakin rendah karena meningkatnya NPF, semakin menurunnya NPF semakin menurunnya risiko pembayaan bermasalah pembayaran murabahah yang diberikan oleh bank syariah akan mengalami kenaikan. Membuktikan bahwa adanya indakasi semakin meningkatnya bank syariah mampu dalam menarik kembali pembiayaan yang disalurkannya khususnya pembiayaan murabahah, meningktnya banyaknya modal pinjaman yang kembali ke bank, maka berdampak pada modal bank yang disediakan untuk diberikan ke masyarakat bertambah. Pihak bank harus juga menekan atau mengontrol adanya peningkatan jumlah NPF, jika hal ini berkelanjutan akan berdampak menurunnya dana yang dimiliki oleh bank. NPF dapat menurunkan jumlah dana, sehingga naiknya tingkat nilai NPF menyebabkan mjumlah pembiayaan murabahah turun. Adanya peningkatan NPF mengindikasikan bahwa usaha perbankan syariah untuk mengontrol jumlah pembiayaan yang yang mempunyai masalah, dengan ini dapat menurunkan tingkat NPF yang akan berpengaruh terhadap peningkatan tingkat pengembalian bank syariah, dan secara tidak langsung akan mempeunyai pengaruh terhadap image public akan mempunyai penilaian terhadap bank syariah tidak mampu melaksanakan fungsinya, hal ini akan berdampak juga terhadap nama suatu bank menurun atau tingkat kepercayaan kepada bank akan turun. Hasil riset kondusif teori dan konsisten dengan hasil riset Gumilarty (2016), Angraini (2016) dan Sulistya (2017). Tetapi bertentangan dengan hasil penelitian dari Prasasti (2011), Wardiantika dan Kusumaningtias (2014), dan Umi (2016), telah membuktikan pembayaran tidak dipengaruhi oleh NPF. 


\section{KESIMPULAN}

Kesimpulan dari hasil riset ini bahwa, perbandingan rasio kecukupan CAR berdampak pada pembayaran/pembiayaan murabahah, naik turunnya pembayaran murabahah dipengaruhi oleh menurunnya dan meningkatnya perbandingan rasio kecukupan. Pembayaran/pembiayaan murabahah tidak dipengaruhi oleh Rasio Pembiayaan pada Deposito $(F D R)$, berarti peningkatan maupun penurunan pembayaran murabahah tidak dipengaruhi oleh meningkatnya dan menurunnya tingkat mampu tidaknya bank untuk membayar hutang jangka pendeknya dan pembiayaan permohonan kredit dari publik. Meskipun tidak FDR tidak berdampak terhadap pembayaran/pembiayaan murabahah, tetap pihak bank syariah harus berhati-hati dalam memberikan pembayaran/pembiayaan tidak hanya dengan mendapatkan profit atau dalam waktu cepat untuk meningkatkan asetnya. Non Performing Financing (NPF) mempunyai dampak berlawanan arah terhadap pembayaran/pembiayaan murabahah, artinya hasil riset ini menunjukkan dengan adanya peningkatan dan penurunan Non Performing Financing (NPF) maka pembayaran/pembiayaan murabahah juga akan menurun atau akan mengalami kenaikan. Pembiayaan bermasalah atau tingkat risiko pembiayaan yang merupakan ketidakpastian (NPF) meningkat akan mempengaruhi menurunnya pembayaran/pembiayaan murabahah, dan sebaliknya jika tingkat risiko pembiayaan yang merupakan ketidak pastian menurun maka akan mempengaruhi meningkatnya pembayaran/pembiayaan murabahah. Hasil riset juga membuktikan bahwa variabel independen yaitu NPF, FDR, CAR yang dipakai dalam model riset ini secara simultan menjelaskan variabel pembiayaan murabahah, dan sebesar 0,207 atau 20,7\% variasi ke tiga variabel independen (CAR, FGR, dan NPF) mampu menjelaskan sebagian $(20,7 \%)$ variasi yang terjadi dalam variabel dependen (pembiayaan murabahah).

Disarankan kepada pihak BPR Syariah khususnya di Kabupaten Provinsi Jawa Timur harus kontinyu untuk tetap mengoptimalkan aktivitas usahanya, agar terkontrolnya pembiayaan bermasalah tidak melebihi atau minimal sama dengan standar yang ditentukan, sehingga jumlah aktiva yang dimiliki mengalami kenaikan, seluruh modal yang disalurkan dalam bentuk kredit dan penempatan di bank lain juga akan mengalami kenaikan, serta secara langsung pendapatan operasional dan profit yang didapat pada periode ke depan terus mengalami kenaikan. Keterlibatan pihak pejabat Bank Syariah dalam hal melakukan kontrol dan mengevaluasi penyaluran pembiayaan khususnya pembiayaan murabahah harus secara kontinyu dan berkelanjutan. Dengan tujuan mengamankan investasi publik yang sudah dipercayakan kepada Bank Syariah. Harapan untuk riset yang akan datang dapat dengan menambah obyek atau variable penelitian yang juga sangat penting dan mempunyai dampak bagi tingkat kesehatan suatu bank termasuk bank syariah yaitu good corporate governance, sehingga akan menambah kontribusi kepada pihak manajemen dan shareholder suatu bank syariah. Corporate governance merupakan salah satu cara atau mekanisme untuk meyakinkan publik yang telah menanamkan dananya atau investasinya ke bank syariah. Banka syarah sebagai pihak yang menyalurkan dan menerima dana dari publik harus mampu mengelola perusahaan dengan baik, harus menjalankan fungsinya sesuai dengan ketentuan dan melaksanakan tugas dan tanggungjawab semata-mata untuk kepentingan perusahaan dalam hal ini juga investor atau nasabah.

\section{DAFTAR PUSTAKA}

Adzimah, R. H. (2017). Pengaruh Capital Adequacy Ratio (CAR) dan Financing to Deposit Ratio (FDR) terhadap Pembiayaan Murabahah dengan Non Performing Financing (NPF) sebagai Variabel Moderating (Studi Kasus pada Bank Umum Syariah di 
Indonesia Periode 2012-2016). Skripsi. Fakultas Ekonomi dan Bisnis Islam Institut Agama Islam Negeri Salatiga.

Ali, H. \& Miftahurrohman. (2016). Determinan yang Mempengaruhi Pembiayaan Murabahah pada Perbankan Syariah di Indonesia. Jurnal Bisnis dan Manajemen Vol. 6 No. 1 April.

Angraini, L. (2016). Analisis Pengaruh Sertifikat Bank Indonesia (SBIS), Non Performing Financing (NPF), Kurs, dan Inflasi terhadap Pembiayaan Murabahah pada perbankan syariah di Indonesia. Skripsi. Universitas Islam Negeri Syarif Hidayatullah Jakarta.

Antonio, M. S. (2011). Bank Syariah dari Teori ke Praktik. Jakarta: Gema Insani Press.

Bank Indonesia. (1998). Undang-Undang Nomor 10 Tahun 1998 Tentang Perbankan. Undang-Undang Nomor 10 Tahun 1998 Tentang Perbankan. https://doi.org/10.1007/s13398-014-0173-7.2

Bank Indonesia. (2011). Peraturan Bank Indonesia Nomor: 13/1/PBI/2011 Tentang Penilaian Tingkat Kesehatan Bank Umum. Peraturan Bank Indonesia.

Cahyono, H. (2018). Sambutan Ketua OJK Regional 4 Jawa Timur dalam Acara Evaluasi Kinerja dan Feed Vack Pengawasan Semeter II Tahun 2018 serta Capacity Building Pengurus dan Dewan Pengawas Syariah. Pada Bank Pembiayaan Rakyat Syariah (BPRS) Se-Jawa Timur. Batu-Malang. https://www.kabarbisnis.com/read/2887994/selama-2018-kinerja-bpr-syariah-di-jatimmakin-berkah

Dendawijaya, L. (2005). Manajemen Perbankan. Edisi Kedua. Cetakan Kedua. Ghalia Indonesia. Bogor Jakarta.

Dyatama, A. N. dan Imamrudin Y. (2015). Determinan Jumlah Pembiayaan Bank Syariah di Indonesia. Jurnal Ekonomi dan Studi Pembangunan. Vol. 16 No. 1 April.

Endriana, W. (2015). Analisis Pengaruh Non Performing Financing dan Financing to Deposit Ratio terhadap Volume Pembiayaan pada Perbankan Syariah di Indonesia dengan Dana Pihak Ketiga sebagai Variabel Mediasi. JRKA Volume 1 No. 1.

Fahruddin, M. (2009). Pengaruh Inflasi, Capital Adequacy Ratio, Credit Risk, Dana Pihak Ketiga dan Jaringan terhadap Pembiayaan pada Bank Umum Syariah. Skripsi. Program Studi Keuangan Islam Jurusan Muamalah Universitas Islam Negeri Sunan Kalijaga. Yogyakarta.

Gumilarty,G.R.M. (2016). Analisis Pengaruh DPK, NPF, ROA, Penempatan Dana pada SBIS, dan Tingkat Bagi Hasil terhadap Pembiayaan Bagi Hasil. Skripsi. Universitas Diponegoro.

Katmas, E. (2014). Pengaruh Faktor Eksternal dan Internal terhadap Volume Pembiayaan Perbankan Syariah di Indonesia. Sripsi. Program Studi Muamalat UIN Syarif Hidayatullah. Jakarta.

Kusnianingrum, D. (2016). Determinan Pembiayaan Murabahah (Studi Pada Bank Syariah Mandiri). Jurnal Ilmu dan Riset Akuntansi. Vol. 5, No. 1, Januari.

Lestari, S. S. (2014). Analisis Faktor-faktor yang Mempengaruhi Pembiayaan Murabahah Bank Umum Syariah di Indonesia. Skripsi. Institut Pertanian Bogor.

Muhammad. (2005). Bank Syariah Problem dan Prospek perkembangan di Indonesia. Yogyakarta: Graha Ilmu.

Muhammad, D. S. (2009). Akuntansi Perbakan Syariah. Yogyakarta: Trust Media Publishing.

Mizan. (2017). Pengaruh DPK, NPF, DER dan ROA terhadap Pembiayaan Murabahah pada Bank Umum Syariah .Jakarta.

Nurbaya, F. (2013). Analisis Pengaruh CAR, ROA, FDR, Dan Dana Pihak Ketiga (DPK) Terhadap Pembiayaan Murabahah Periode Maret 2001 - Desember 2009 (Studi Kasus Pada PT. Bank Muamalat Indonesia, Tbk.). Skripsi. Universitas Diponegoro. Semarang. 
Prasasti, D. (2014). Analisis Pengaruh Financing To Deposit Ratio (FDR), Non Performing Financing (NPF), Spread Bagi Hasil, dan Tingkat Bagi Hasil terhadap Pembiayaan Bagi Hasil. Skripsi. Universitas Diponegoro.

Prastanto. (2013). Faktor yang Mempengaruhi Pembiayaan Murabahah pada Bank Umum Syariah di Indonesia. Accounting Analysis Journal. AAJ 2 (1). 83-88. http://journal.unnes.ac.id/sju/index.php/aaj.

Rahman, F. dkk. (2017). Pengaruh Jumlah Dana Pihak Ketiga dan Financing to Deposit Ratio terhadap Pembiayaan Murabahah. e-Proceeding of Management: Vol.4. No.1 April.

Rimadhani, M. (2011). Analisis Variabel-Variabel yang Mempengaruhi Pembiayaan Murabahah pada Bank Syariah Mandiri Periode 2008-2011. Media Ekonomi Vol. 19, No. 1, April.

Rivai, V., dan Andaria P. (2006). Credit Management Handbook, Teori, Konsep, Prosedur dan Aplikasi praktisi Mahasiswa, Bankir, dan Nasabah. Jakarta : PT Raja Grafindo Persada.

Rivai, V. dan Arifin, A. (2010). Islamic Banking: Sebuah Teori Konsep dan Aplikasi. Jakarta: Bumi Askara.

Rivai, V. dkk, (2013). Financial Institution Management (Manajemen Kelembagaan Keuangan) disajikan secara lengkap dari Teori hingga Aplikasi, (Jakarta: PT. Grafindo Persada,

Rose, P. S. dan James W. K. (1995). Financial Institution : "Understanding and managing financial services", Richard D. Irwin, Inc., USA

Sari, W. P. (2011). Pengaruh DPK, FDR, NPF, dan Suku Bunga Pinjaman Konsumtif Bank Umum Konvensional, terhadap Pembiayaan Murabahah Perbankan Syariah di Indonesia. Skripsi. Universitas Islam Negeri Syarif Hidayatullah Jakarta.

Siamat, D. (2005) .Manajemen Lembaga Keuangan; Kebijakan Moneter dan Perbankan Edisi.5. Jakarta: Fakultas Ekonomi Universitas Indonesia. https://doi.org/10.1515/ci.2005.27.6.25

Sulistya, A. D. (2017). Pengaruh Dana Pihak Ketiga (Dpk), Non Performing Financing (NPF) dan Financing To Deposit Ratio (FDR) terhadap Pembiayaan Murabahah pada Perbankan Syariah Di Indonesia. Skripsi. Universitas Negeri Yogyakarta.

Umi, Y. M. (2016). Analisis Pengaruh Dana Pihak Ketiga (DPK), Capital Adequacy Ratio (CAR), Non Performing Financing (NPF), Financing To Deposit Ratio (FDR), Quick Ratio (QR), dan Return On Asset (ROA), terhadap Pembiayaan Murabahah pada Bank Umum Syariah Periode 2010-2013. Skripsi. Universitas Islam Negeri Sultan Sarif Kasim Riau.

Usanti T. dan Abudu. S. (2013). Transaksi Bank Syariah,. Jakarta: Bumi Aksara,

Vogel, F.E. and Samuel L. H. (1998). Islamic Law and Finance: Religion, Risk and Return. Cambridge: The Kluwer Law Internationa.

Wardiantika, L. dan Rohmawati K. (2014). Pengaruh DPK, CAR, NPF, dan SWBI terhadap Pembiayaan Murabahah pada Bank Umum Syariah Tahun 2008-2012. Jurnal Ilmu Manajemen Vol. 2 No. 4 Oktober.

https://www.syariahbukopin.co.id/id/produk-dan-jasa/pembiayaan/murabahah

https://www.kabarbisnis.com/read/2887994/selama-2018-kinerja-bpr-syariah-di-jatim-makinberkah 